\title{
TINGKAT PENGETAHUAN DAN SIKAP MASYARAKAT DI DESA PASAR VI KUALANAMU TENTANG KESEHATAN REPRODUKSI REMAJA BERDASARKAN KEIKUTSERTAAN PADA KEGIATAN SOSIALISASI
}

\author{
RIRI SAFITRI \\ Institut Kesehatan Medistra Lubuk Pakam \\ Jl. Sudirman No 38 Lubuk Pakam \\ e-mail : ririsafitribiologi@gmail.com \\ DOI : https://doi.org/10.35451/jkg.v2i2.406
}

\begin{abstract}
Adolescence is a transition period from childhood to adulthood, some adolescents do not know and understand about reproductive health, for example about menstruation and the occurrence of pregnancy. By participating in reproductive health socialization activities, it can increase knowledge about reproductive health. So research is needed on the level of knowledge and attitudes of the community in Pasar VI Kualanamu Village, Beringin District, regarding reproductive health based on participation in socialization activities. The purpose of this study was to determine differences in the level of knowledge and attitudes of the community in Pasar VI Kualanamu Village, Beringin District regarding Reproductive health based on participation in the socialization activities. And aims to determine the success of the dissemination of reproductive health carried out in the village market VI Kualanamu District Banyan. This research is a comparative study with a cross sectional approach. The research sample was taken by accidental sampling technique with a total of 64 respondents. This research was conducted in January 2020 in Pasar VI Village Kualanamu, Beringin District. The instruments used were questionnaire characteristics of respondents, questionnaires about knowledge of reproductive health, and attitudes about reproductive health health. The data analysis technique used in this study was the Mann Whitney $U$ test. the results of this study show that respondents who participated in socialization (counseling) about reproductive health gained better knowledge about reproductive health. The results of the analysis of the use of the Mann Whitney $U$ test are that there is no significant difference in the level of knowledge and attitudes in the groups participating in the socialization and groups not participating in the socialization.
\end{abstract}

Keywords : Adolescent Reproductive Health, Knowledge 


\section{PENDAHULUAN}

Masa remaja merupakan masa transisi dari masa anak-anak menuju dewasa. Remaja akan mengalami perubahan fisik yang cepat ketika remaja memasuki masa puber. Salah satu dari perubahan fisik tersebut adalah kemampuan untuk melakukan proses reproduksi. Tetapi banyak memperlihatkan sebagian remaja belum mengetahui dan memahami tentang kesehatan reproduksi, misalnya tentang menstruasi dan terjadinya kehamilan (Setianti, Y et al, 2013).

Permasalahan pada remaja yang paling menonjol yang berkaitan dengan masa tumbuh kembangnya adalah seksualitas, penggunaan obat-obatan terlarang dan HIV/AIDS (BKKBN, 2012).

Orang tua di kawasan pedesaan masih minim dalam hal membicarakan mengenai reproduksi dengan remaja. Hal tersebut dapat dilatarbelakangi karena kurangnya pengetahuan orang tua dan masih menganggap hal yang tabu. Oleh karena itu para orang tua perlu mendapatkan informasi tentang kesehatan reproduksi.

Informasi kesehatan reproduksi dapat diperoleh salah satunya dari ikut serta dalam kegiatan sosialisasi (penyuluhan). Menurut Purnomo (2009) memperlihatkan bahwa tingkat pengetahuan dan perilaku seksual remaja menjadi lebih baik karena adanya kegiatan penyuluhan kesehatan reproduksi.

Kegiatan sosialisasi (penyuluhan) tentang kesehatan reproduksi, telah dilakukan di desa pasar VI Kualanamu pada bulan mei 2019 yang dihadiri oleh para orang tua dan remaja, namun masih beberapa dari masyarakat yang ikut serta dalam kegiatan tersebut.

Dengan keikutsertaan dalam kegiatan sosialisasi kesehatan reproduksi, maka dapat meningkatkan pengetahuan tentang kesehatan reproduksi. Maka diperlukan penelitian tentang tingkat pengetahuan dan sikap masyarakat di Desa Pasar VI Kualanamu Kecamatan Beringin tentang kesehatan reproduksi berdasarkan keikutsertaan pada kegiatan sosialisasi.

Adapun tujuan penelitian ini untuk mengetahui perbedaan tingkat pengetahuan dan sikap masyarakat di Desa Pasar VI Kualanamu Kecamatan Beringin tentang kesehatan Reproduksi berdasarkan keikutsertaan pada kegiatan sosialisasi. Serta bertujuan untuk mengetahui keberhasilan dari sosialisasi kesehatan reproduksi yang di lakukan di desa pasar VI Kualanamu Kecamatan beringin.

\section{METODE PENELITIAN}

Penelitian ini merupakan penelitian komparatif dengan pendekatan cross sectional. Sampel penelitian diambil dengan teknik accidental sampling dengan jumlah 64 responden. Penelitian ini dilakukan pada bulan januari 2020 di Desa Pasar VI Kualanamu Kecamatan Beringin.

Instrumen yang digunakan berupa kuesioner karakteristik responden, kuesioner pengetahuan tentang kesehatan reproduksi dan sikap tentang kesehatan kesehatan reproduksi.

Teknik analisis data yang digunakan dalam penelitian ini adalah uji U Mann Whitney.

\section{HASIL PENELITIAN} Kegiatan Sosialisasi (Penyuluhan)

Gambar 1. Kegiatan Sosialisasi (Penyuluhan) Kesehatan Reproduksi Remaja

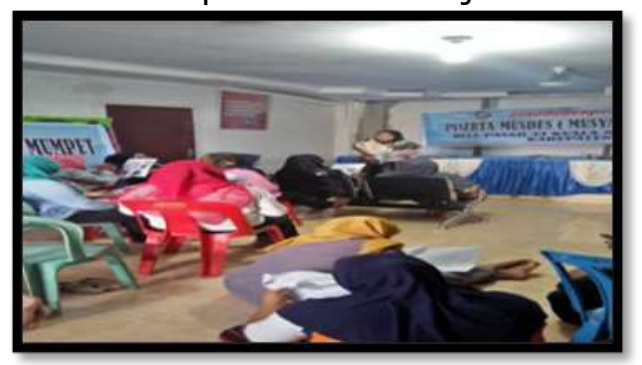


Kegiatan sosialisasi/penyuluhan tentang kesehatan reproduksi, telah dilakukan di desa pasar VI Kualanamu pada bulan mei 2019. Kegiatan berjalan dengan baik dan memperoleh respon yang baik dari peserta yang hadir.

\section{Karakteristik Responden}

Tabel 1. Gambaran distribusi karakteristik Responden di Desa Pasar VI Kualanamu Kecamatan Beringin $(n=32)$

\begin{tabular}{lcccc}
\hline \multicolumn{1}{c}{$\begin{array}{c}\text { Karakter } \\
\text { istik } \\
\text { Responden }\end{array}$} & $\begin{array}{c}\text { Ikut Serta } \\
\text { Sosialisasi }\end{array}$ & \multicolumn{2}{c}{$\begin{array}{c}\text { Tidak Ikut } \\
\text { serta } \\
\text { Sosialisasi }\end{array}$} \\
\cline { 2 - 5 } $\begin{array}{l}\text { Jenis } \\
\text { kelamin }\end{array}$ & $\mathrm{n}$ & $\%$ & $\mathrm{n}$ & $\%$ \\
$\begin{array}{l}\text { Laki-laki } \\
\text { Perempuan } \\
\text { Usia }\end{array}$ & 2 & 6,2 & 12 & 37,5 \\
$\begin{array}{l}13-21 \\
\text { tahun }\end{array}$ & 17 & 53,8 & 20 & 62,5 \\
$>21$ tahun & 15 & 46,9 & 7 & 21,9 \\
Total & 32 & 100 & 32 & 100 \\
\hline
\end{tabular}

Dari tabel 1 diketahui bahwa karakteristik responden berdasarkan jenis kelamin yang paling banyak berpartisipasi dalam penelitian ini berjenis kelamin perempuan yaitu sebanyak 30 responden perempuan $(93,8 \%)$ pada kelompok yang ikut serta sosialisasi dan 20 responden perempuan $(62,5 \%)$ pada kelompok yang tidak ikut serta sosialisasi. Sedangkan untuk responden laki-laki pada kelompok yang ikut sosialisasi sebanyak 2 responden $(6,2 \%)$ dan responden laki-laki pada kelompok yang tidak ikut sosialisasi sebanyak 12 responden $(37,5 \%)$.

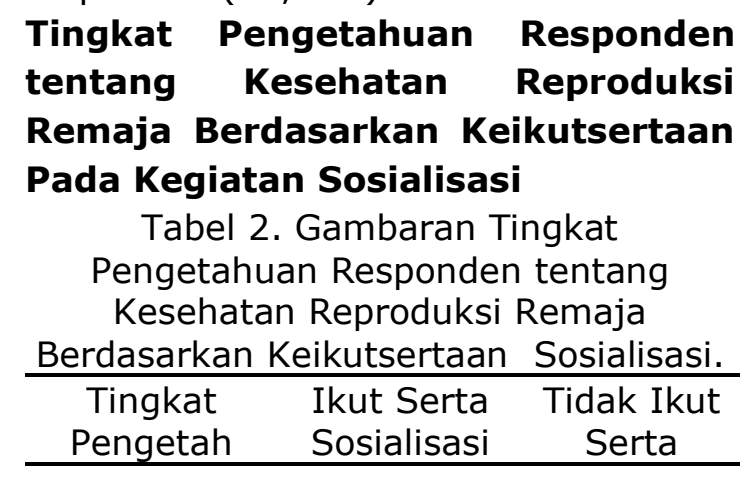

\begin{tabular}{lcccc}
\hline \multirow{2}{*}{ uan } & \multicolumn{3}{c}{$\begin{array}{c}\text { Sosiali } \\
\text { sasi }\end{array}$} \\
\cline { 2 - 5 } & $\mathrm{F}$ & $\%$ & $\mathrm{~F}$ & $\%$ \\
\hline Tinggi & 17 & 53,1 & 0 & 0 \\
Sedang & 10 & 31,3 & 3 & 9,4 \\
Rendah & 5 & 15,6 & 29 & 90,6 \\
\hline Total & $\mathbf{3 2}$ & $\mathbf{1 0 0}$ & $\mathbf{3 2}$ & $\mathbf{1 0 0}$ \\
\hline
\end{tabular}

Dari tabel 2 diketahui tingkat pengetahuan responden tinggi pada kelompok yang ikut serta sosialisasi sebanyak 17 responden (53,1\%), sedangkan tingkat pengetahuan responden tinggi pada kelompok yang tidak ikut sosialisasi sebanyak 0 responden $(0 \%)$.

Tingkat pengetahuan responden sedang pada kelompok yang ikut serta sosialisasi sebanyak 10 responden $(31,3 \%)$, sedangkan tingkat pengetahuan responden sedang pada kelompok yang tidak ikut sosialisasi sebanyak 3 responden $(9,4 \%)$.

Tingkat pengetahuan responden rendah pada kelompok yang ikut serta sosialisasi sebanyak 5 responden $(15,6 \%)$, sedangkan tingkat pengetahuan rendah pada kelompok yang tidak ikut serta sosialisasi sebanyak 29 responden (90,6\%).

\section{Sikap Responden tentang Kesehatan Reproduksi Remaja Berdasarkan Keikutsertaan pada Kegiatan Sosialisasi}

Tabel 3. Gambaran Sikap Responden tentang Kesehatan Reproduksi Remaja Berdasarkan Keikutsertaan Pada Kegiatan Sosialisasi.

$\begin{array}{ccc} & \text { Ikut Serta } & \text { Tidak Ikut } \\ \text { Sikap } & \text { Sosialisasi } & \text { Serta } \\ & & \text { Sosialisasi }\end{array}$

\begin{tabular}{lcccc} 
& $\mathrm{n}$ & $(\%)$ & $\mathrm{n}$ & $(\%)$ \\
\hline Sangat & 19 & 59,4 & 0 & 0 \\
baik & & & & \\
Baik & 11 & 34,4 & 0 & 0 \\
$\begin{array}{l}\text { Cukup } \\
\text { Kurang }\end{array}$ & 2 & 6,2 & 3 & 9,4 \\
baik & 0 & 0 & 29 & 90,6 \\
$\begin{array}{l}\text { Sangat } \\
\text { kurang } \\
\text { baik }\end{array}$ & 0 & 0 & 0 & 0 \\
Total & $\mathbf{3 2}$ & $\mathbf{1 0 0}$ & $\mathbf{3 2}$ & $\mathbf{1 0 0}$
\end{tabular}


Dari Tabel 3. Menunjukkan bahwa sikap responden yang memiliki sikap sangat baik sebesar 19 responden $(59,4 \%)$ yaitu pada kelompok yang ikut serta sosialisasi, sedangkan pada kelompok yang tidak ikut sosialisasi sebesar 0 respoden $(0 \%)$.

Sikap responden yang memiliki sikap baik sebesar 11 responden $(34,4 \%)$ yaitu pada kelompok yang ikut serta sosialisasi, sedangkan pada kelompok yang tidak ikut sosialisasi sebesar 0 responden (0\%).

Sikap responden yang memiliki sikap cukup sebesar 2 responden $(6,2 \%)$ yaitu pada kelompok yang ikut sosialisasi, sedangkan pada kelompok yang tidak ikut sosialisasi sebesar 3 responden $(9,4 \%)$.

Sikap responden yang memiliki sikap kurang baik sebesar 0 responden (0\%) yaitu pada kelompok yang ikut sosialisasi, sedangkan pada kelompok yang tidak ikut sosialisasi sebesar 29 responden $(90,6 \%)$.

\section{Perbedaan Tingkat Pengetahuan dan Sikap Responden tentang Kesehatan Reproduksi Remaja Berdasarkan Keikutertaan pada Kegiatan Sosialisasi}

Hasil analisis penggunaan uji $U$ Mann Whitney untuk melihat adanya perbedaan tingkat pengetahuan dan sikap responden tentang kesehatan reproduksi remaja berdasarkan keikutsertaan pada kegiatan sosialisasi dapat dilihat pada tabel berikut :

Tabel 4. Analisis Perbedaan Tingkat

Pengetahuan dan Sikap Responden tentang Kesehatan Reproduksi Remaja

Berdasarkan Keikutsertaan pada Kegiatan Sosialisasi

\begin{tabular}{ccc}
\hline Variabel & \multicolumn{2}{c}{ Uji U Mann Whitney } \\
\cline { 2 - 3 } & $\begin{array}{c}\text { Nilai U } \\
\text { Statistik } \\
\text { Uji }\end{array}$ & $\begin{array}{c}\text { Nilai U Tabel } \\
\text { Mann } \\
\text { Whitney } \\
\text { pada Taraf } \\
\text { signifikansi } \\
=0.05(5 \%)\end{array}$ \\
\hline Tingkat & 3 & $0($ One- \\
\hline
\end{tabular}

\begin{tabular}{lcc}
\hline Pengetahuan & & Tailed \\
& & Testing) \\
Sikap & 7 & 4 (One- \\
& & Tailed \\
& & Testing) \\
\hline
\end{tabular}

4. Pembahasan

\section{Kegiatan Sosialisasi (Penyuluhan)}

Kegiatan sosialisasi/penyuluhan tentang kesehatan reproduksi, telah dilakukan di desa pasar VI Kualanamu pada bulan mei 2019. Kegiatan berjalan dengan baik dan memperoleh respon yang baik dari peserta yang hadir. Hal ini menunjukkan bahwa kegiatan sosialisasi (penyuluhan) kesehatan reproduksi, menjadi salah satu cara yang baik untuk memberikan informasi kepada masyarakat tentang kesehatan reproduksi. Hal ini sesuai dengan penelitian Budyantara N, et al (2011) menyatakan bahwa para responden memberikan kategori baik terhadap kegiatan penyuluhan tentang kesehatan reproduksi (3)

\section{Karakteristik Responden}

Dari tabel 1 diketahui bahwa karakteristik responden berdasarkan jenis kelamin yang paling banyak berpartisipasi dalam penelitian ini berjenis kelamin perempuan yaitu sebanyak 30 responden perempuan $(93,8 \%)$ pada kelompok yang ikut serta sosialisasi dan 20 responden perempuan $(62,5 \%)$ pada kelompok yang tidak ikut serta sosialisasi. Sedangkan untuk responden laki-laki pada kelompok yang ikut sosialisasi sebanyak 2 responden $(6,2 \%)$ dan responden laki-laki pada kelompok yang tidak ikut sosialisasi sebanyak 12 responden (37,5\%).

Menurut Ariani (2014) bahwa remaja laki-laki dan remaja perempuan memiliki tingkat kesadaran yang berbeda akan pentingnya informasi terkait kesehatan reproduksi. Biasanya remaja laki-laki memiliki kesadaran yang kurang baik dibandingkan dengan 
remaja perempuan, sehingga akan bersikap acuh dan terkesan tidak peduli.

Dari tabel 1. Diketahui bahwa karakteristik responden berdasarkan usia pada kelompok yang ikut serta dalam sosialisasi adalah tergolong usia remaja (13- 21 tahun) yaitu sebanyak 17 responden $(53,1 \%)$ dan usia dewasa (>21 tahun) yaitu sebanyak 15 responden $\quad(46,9 \%)$. Sedangkan karakteristik responden bedasarkan usia pada kelompok yang tidak ikut sosialisasi adalah tergolong usia remaja (13-21 tahun) yaitu sebanyak 25 responden $(78,1 \%)$ dan usia dewasa (>21) yaitu sebanyak 7 responden (21,9\%). Menurut Hurlock (1999) pembagian rentang usia remaja antara 13-21, yang dibagi pula dalam masa remaja awal usia 13/14 tahun sampai 17 tahun, dan massa remaja akhir 17 sampai 21 tahun.

Pentingnya Keikutsertaan usia remaja dan dewasa dalam sosialisasi kesehatan reproduksi, dikarenakan usia remaja merupakan usia yang memang harus diberi pengetahuan tentang kesehatan reproduksi, sedangkan pada usia yang tergolong dewasa, keikutsertaan dalam sosialisasi memberikan hal yang positif bagi diri mereka sendiri serta lingkungan sekitar yaitu membantu menyampaikan ke masyarakat sekitarnya tentang kesehatan reproduksi.

\section{Tingkat Pengetahuan Responden tentang Kesehatan Reproduksi Remaja Berdasarkan Keikutsertaan Pada Kegiatan Sosialisasi}

Dari tabel 2 diketahui tingkat pengetahuan responden tinggi pada kelompok yang ikut serta sosialisasi sebanyak 17 responden (53,1\%), sedangkan tingkat pengetahuan responden tinggi pada kelompok yang tidak ikut sosialisasi sebanyak 0 responden $(0 \%)$.
Tingkat pengetahuan responden sedang pada kelompok yang ikut serta sosialisasi sebanyak 10 responden $(31,3 \%)$, sedangkan tingkat pengetahuan responden sedang pada kelompok yang tidak ikut sosialisasi sebanyak 3 responden $(9,4 \%)$.

Tingkat pengetahuan responden rendah pada kelompok yang ikut serta sosialisasi sebanyak 5 responden $(15,6 \%)$, sedangkan tingkat pengetahuan rendah pada kelompok yang tidak ikut serta sosialisasi sebanyak 29 responden $(90,6 \%)$.

Dari hasil penelitian diatas menunjukkan bahwa responden yang ikut serta sosialisasi (penyuluhan) tentang kesehatan reproduksi memperoleh pengetahuan yang lebih baik mengenai kesehatan reproduksi. Hal ini sejalan dengan penelitian yang dilakukan Johariyah (2018) yang menunjukkan hasil bahwa perubahan pengetahuan responden sebelum dan setelah dilakukan penyuluhan kesehatan reproduksi remaja tentang kesehatan reproduksi reproduksi remaja dengan pemberian modul berubah menjadi lebih baik dengan adanya peningkatan pengetahuan remaja. Selain itu penelitian yang dilakukan Endarto (2009) memperlihatkan bahwa tingkat pengetahuan dan perilaku seksual remaja menjadi lebih baik karena adanya kegiatan penyuluhan kesehatan reproduksi.

\section{Sikap Responden tentang Kesehatan Reproduksi Remaja Berdasarkan Keikutsertaan pada Kegiatan Sosialisasi}

Dari Tabel 3. Menunjukkan bahwa sikap responden yang memiliki sikap sangat baik sebesar 19 responden $(59,4 \%)$ yaitu pada kelompok yang ikut serta sosialisasi, sedangkan pada kelompok yang tidak ikut sosialisasi sebesar 0 respoden $(0 \%)$.

Sikap responden yang memiliki sikap baik sebesar 11 responden 
$(34,4 \%)$ yaitu pada kelompok yang ikut serta sosialisasi, sedangkan pada kelompok yang tidak ikut sosialisasi sebesar 0 responden (0\%).

Sikap responden yang memiliki sikap cukup sebesar 2 responden $(6,2 \%)$ yaitu pada kelompok yang ikut sosialisasi, sedangkan pada kelompok yang tidak ikut sosialisasi sebesar 3 responden $(9,4 \%)$.

Sikap responden yang memiliki sikap kurang baik sebesar 0 responden $(0 \%)$ yaitu pada kelompok yang ikut sosialisasi, sedangkan pada kelompok yang tidak ikut sosialisasi sebesar 29 responden $(90,6 \%)$.

Dari hasil penelitian diatas menunjukkan bahwa sikap responden tentang kesehatan reproduksi pada kelompok yang ikut serta sosialisasi memiliki sikap yang cukup hingga sangat baik, sedangkan sikap responden pada kelompok yang tidak ikut sosialisasi memiliki sikap yang kurang baik hingga cukup. Hal tersebut dikarenakan pada kelompok yang ikut sosialisasi memiliki tingkat pengetahuan yang lebih baik tentang kesehatan reproduksi, dimana tingkat pengetahuan mempengaruhi sikap seseorang.

Hal ini sejalan dengan penelitian yang dilakukan oleh Wijaya (2014) menunjukkan hasil bahwa remaja akan bersikap baik karena didukung oleh pengetahuan yang baik pula.

Menurut Widyastuti

(2009) mengemukakan bahwa remaja akan lebih bertanggung jawab terhadap perilaku dan sikapnya jika memiliki pengetahuan yang baik tentang kesehatan reproduksi remaja.

\section{Perbedaan Tingkat Pengetahuan dan Sikap Responden tentang Kesehatan Reproduksi Remaja Berdasarkan Keikutertaan pada Kegiatan Sosialisasi}

Tabel 4 menunjukkan hasil analisis perbedaan tingkat pengetahuan dan sikap responden tentang kesehatan reproduksi remaja berdasarkan keikutsertaan pada kegiatan sosialisasi menggunakan uji $U$ Mann Whitney dengan hasil nilai $U$ statistik uji pada variabel tingkat pengetahuan yaitu 3 dan nilai $U$ tabel Mann Whitney pada taraf signifikansi $=0,05(5 \%)$ yaitu 0 pada One-Tailed Testing, Oleh karena itu nilai $U$ statistik uji lebih besar dari nilai $U$ tabel Mann Whitney yaitu $4>0$, sehingga keputusan $\mathrm{HO}$ diterima, $\mathrm{H} 1$ ditolak yang artinya bahwa tidak ada perbedaan antara variable yang di uji.

Selanjutnya hasil nilai $U$ statistik uji pada variable sikap yaitu 7 dan nilai $U$ tabel Mann Whitney pada taraf signifikansi $=0,05(5 \%)$ yaitu 4 pada One Tailed Testing, oleh karena itu nilai $U$ statistik uji lebih besar dari nilai $U$ tabel Mann Whitney yaitu $7>4$, sehingga keputusan $\mathrm{HO}$ diterima, $\mathrm{H} 1$ ditolak yang artinya bahwa tidak ada perbedaan antara variable yang di uji.

Berdasarkan hasil data diatas bahwa tidak adanya perbedaan signifikan pada tingkat pengetahuan dan sikap pada kelompok yang ikut serta sosialisasi dan kelompok yang tidak ikut sosialisasi, hal tersebut disebabkan karena sumber informasi tentang kesehatan reproduksi tidak hanya dapat diperoleh dari kegiatan sosialisai, tetapi juga dapat diperoleh dari orang yang terdekat seperti orang tua dan keluarga serta lingkungan sekitar seperti sekolah dan media informasi lainnya. Namun keikut sertaan dalam kegiatan sosialiasasi dapat meningkatkan pengetahuan dan sikap menjadi lebih baik lagi.

Menurut penelitian Nufika (2014) bahwa tindakan aktivitas seksual dalam kesesehatan reproduksi remaja dipengaruhi oleh pemberian informasi terkait kesehatan reproduksi dari orang tua, dalam perkembangan nya remaja akan menjadikan orang tua sebagai 
panutan untuk bertindak dan bersikap hingga remaja tumbuh menjadi dewasa.

Selanjutnya menurut penelitian Ernawati (2018) bahwa adapun faktor yang mempengaruhi pengetahuan tentang kesehatan reproduksi remaja di desa yaitu jenis kelamin, jumlah sumber informasi dan pemanfaatan orang tua sebagai sumber informasi.

\section{KESIMPULAN}

Kesimpulan dari hasil penelitian ini adalah bawah menunjukkan bahwa responden yang ikut serta sosialisasi (penyuluhan) tentang kesehatan reproduksi memperoleh pengetahuan yang lebih baik mengenai kesehatan reproduksi. Selanjutnya sikap responden tentang kesehatan reproduksi pada kelompok yang ikut serta sosialisasi memiliki sikap yang cukup hingga sangat baik, sedangkan sikap responden pada kelompok yang tidak ikut sosialisasi memiliki sikap yang kurang baik hingga cukup. Hasil analisis penggunaan uji $U$ Mann Whitney untuk melihat adanya perbedaan tingkat pengetahuan dan sikap responden tentang kesehatan reproduksi remaja berdasarkan keikutsertaan pada kegiatan sosialisasi, diperoleh hasil yaitu tidak adanya perbedaan signifikan pada tingkat pengetahuan dan sikap pada kelompok yang ikut serta sosialisasi dan kelompok yang tidak ikut sosialisasi.

\section{DAFTAR PUSTAKA}

Ariani AP, (2014). Aplikasi metodologi penelitian kebidanan dan kesehatan reproduksi. Jakarta ; Nuha Medika.

BKKBN, (2012). Pedoman Pengelolaan Pusat Informasi dan Konseling Remaja dan Mahasiswa (PIK-R/M), Jakarta.

Budyantara, N \& Jemadi (2011). Persepsi Remaja Terhadap Penyuluhan Kesehatan Reproduksi Remaja diKecamatan Wirobarajan
Yogyakarta. Jurnal MAKSIPRENEUR, vol.I, No.1, Hal. 108-119.

Endarto Y, Purnomo PS. (2009). Hubungan tingkat pengetahuan tentang kesehatan reproduksi dengan perilaku seksual berisiko pada remaja di SMK negeri 4 yogyakarta, Jurnal Kesehatan Surya Medika Yogyakarta.

Ernawati, H. (2018). Pengetahuan Kesehatan Reproduksi Remaja di Daerah Pedesaan. Indonesian Journal for Health Sciences. Vol.02, No.01, Maret, Hal 58-64, ISSN 2549-2748 (online).

Hurlock, E.B. (1999). Perkembangan Anak (Jilid II). Alih bahasa : Tjandrasa dan Zarkasih. Jakarta : Erlangga.

Johariyah, A \& Mariati, T, (2018). Efektivitas Penyuluhan Kesehatan Reproduksi Remaja Dengan Pemberian Modul Terhadap perubahan Pengetahuan Remaja, Jurnal Manajemen Kesehatan Yayasan RS. Dr. Soetomo, vol.4, No., hal 38-46.

Nufika H, Rokhmah D \& Nafikadini, I, (2014). Hubungan Antara Faktor Pribadi Dan Faktor Lingkungan Dengan Tindakan Kesehatan Reproduksi Remaja (Studi Di SMA Negeri 4 Jember). Fakultas Kesehatan Masyarakat Universitas Jember, 1-8.

Setianti, Y dan Komala, L, (2013). Komunikasi Kesehatan Reproduksi Remaja di Pedesaan. Edutech, Tahun 12, Bol. 1, No. 3, Oktober.

Widyastuti, Y., dkk, (2009). Kesehatan Reproduksi. Yogyakarta : Fitrimaya.

Wijaya IM, Agustini NN \& MS, GD, (2014). Pengetahuan Sikap Dan Aktivitas Remaja Sma Dalam Kesehatan Reproduksi Di Kecamatan Buleleng, Jurnal Kesehatan Masyarakat;10(1):3334 